\title{
Alkaline Amylases of Alkalophilic Bacteria ${ }^{\dagger}$
}

\author{
By Masaki Yamamoto, Yoshitake TANakA and \\ Koki HoRIKOSHI
}

The Institute of Physical and Chemical Research

Wako-shi, Saitama-ken 351

Received February 18, 1972

In the previous paper of this series, ${ }^{13}$ it was reported that alkalophilic bacteria, Bacillus No. A-40-2 produced an alkaline amylase, and some properties of this amylase were discussed.

Recently, it has been found that alkalophilic bacteria isolated from soil in Japan produces amylases, whose $\mathrm{pH}$-activity curves can be classified into four types. These findings are discussed in this note.

An isolation medium (II-medium) and isolation method of alkalophilic bacteria were reported previously." Eight strains, A-59, $27-1,124-1,135,169,38-2,13$ and 17-1 were selected from about 300 strains isolated. These bacteria were aerobic, sporeforming, motile and rod-shaped bacteria. It is clear that the all strains should belong to the genus Bacillus. The characteristic point of the bacteria was that the growth was especially good in alkaline media, the optimum $\mathrm{pH}$ for growth being about 10 . Giant colonies of Bacillus No. 38-2 were motile colonies rotating from point of inoculation. Table I summarizes the morphological and cultural characteristics of the isolated strains.

The isolated strains were grown aerobically at $37^{\circ} \mathrm{C}$ in II-medium. After 3 days' incubation with shaking, cells were removed by centrifugation at $6,000 \times g$ for $10 \mathrm{~min}$. Amylase activities of the supernatant fluid were measured at various pH's. A modified blue

\footnotetext{
$\uparrow$ Production of Alkaline Enzyme by Alkaophilic Microorganisms, Part IV.
}

value method ${ }^{11}$ was applied to assay amylase activity. The following buffer systems were used: $\mathrm{pH} 2.5 \sim 6,0.2 \mathrm{M}$ acetate buffer; $\mathrm{pH}$ $5 \sim 8,0.2 \mathrm{M}$ Tris-maleate buffer; $\mathrm{pH} \quad 7 \sim 9$, $0.2 \mathrm{M}$ Tris- $\mathrm{HCl}$ buffer; $\mathrm{pH} \quad 8.5 \sim 13,0.2 \mathrm{M}$ glycine- $\mathrm{NaCl}-\mathrm{NaOH}$ buffer. As shown in Fig. 1, four types of $\mathrm{pH}$-activity curve were observed: type 1, optimum $\mathrm{pH}$ is about 10 ; type 2, optimum $\mathrm{pH}$ are 4 and 10 ; type 3 , optimum $\mathrm{pH}$ are 4 and 9 ; type 4 , optimum $\mathrm{pH}$ is 4 and shoulder at $\mathrm{pH} 10$. Type 2,3 and 4 may be a mixture of two or more amylases. Bacillus No. 38-2 amylase which has type 3 pH-activity curve was purified about 50 fold, but still has same pH-activity curve. However, hydrolysis rate at $\mathrm{pH} 4.7$ and 8.5 were remarkably different. Further details will be reported elsewhere. It is noteworthy that those four types of $\mathrm{pH}$-activity curve were also observed under the tested culture conditions as shown in Table II.

The culture broth was mixed with $0.1 \mathrm{M}$ Borax- $\mathrm{NaOH}$ buffer ( $\mathrm{pH} 10.0)$ in the presence or absence of $10 \mathrm{mM} \mathrm{CaCl}_{2}$, incubated at $55^{\circ} \mathrm{C}$ or $60^{\circ} \mathrm{C}$ for $15 \mathrm{~min}$, and the residual activity was measured at $\mathrm{pH} 10.0$. As shown in Table III, all of the amylases tested were stabilized by $\mathrm{Ca}^{2+}$. Amylases which have type 1 pH-activity curve were thermolabile and competely inactivated by heating at $55^{\circ} \mathrm{C}$ for $15 \mathrm{~min}$. Amylases of type 2 and 4 were fairly heat stable, and about $70 \sim 95 \%$ of activity was remained after heating at $55^{\circ} \mathrm{C}$ for 15 min. Bacillus No. 38-2 amylase which 


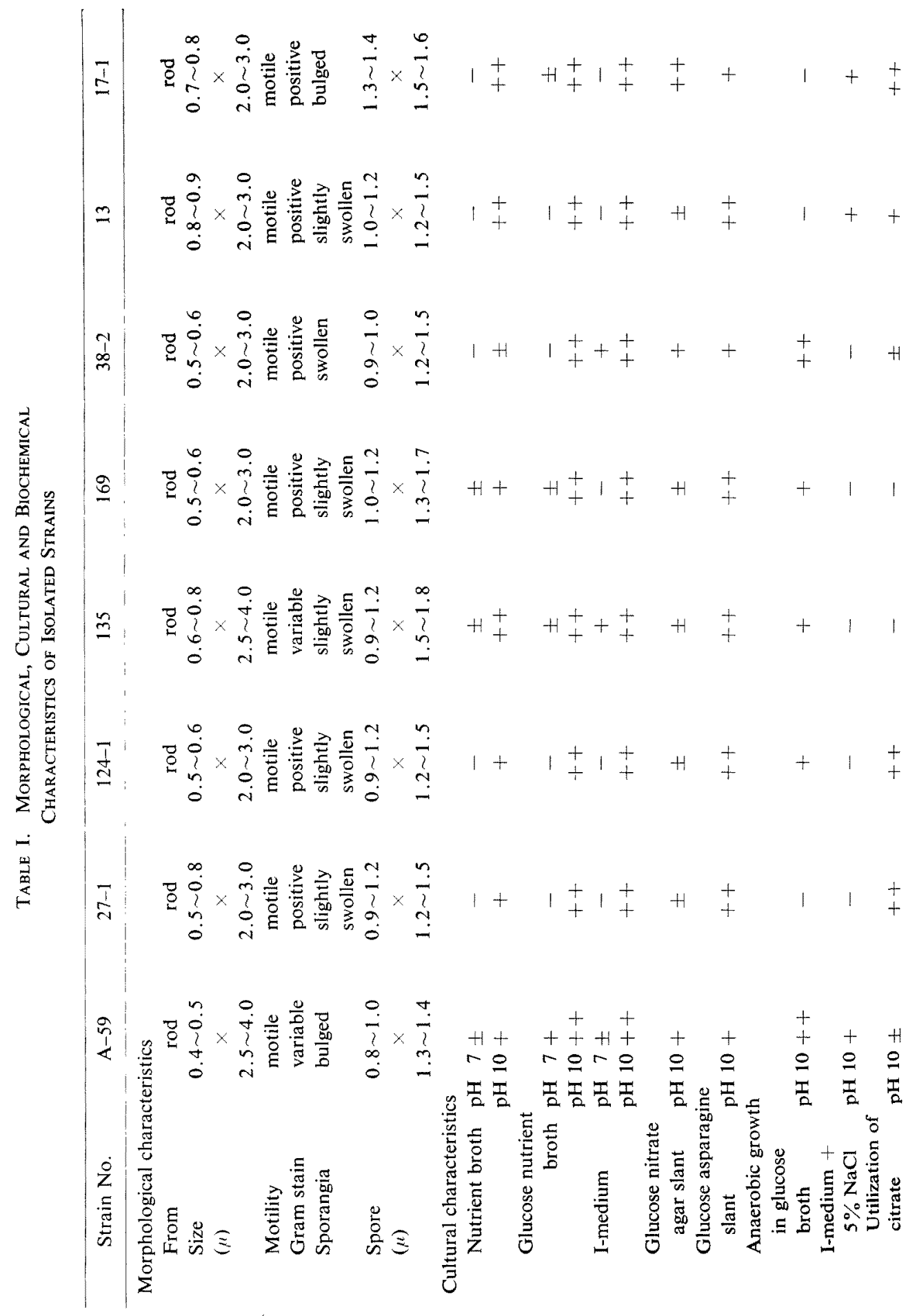




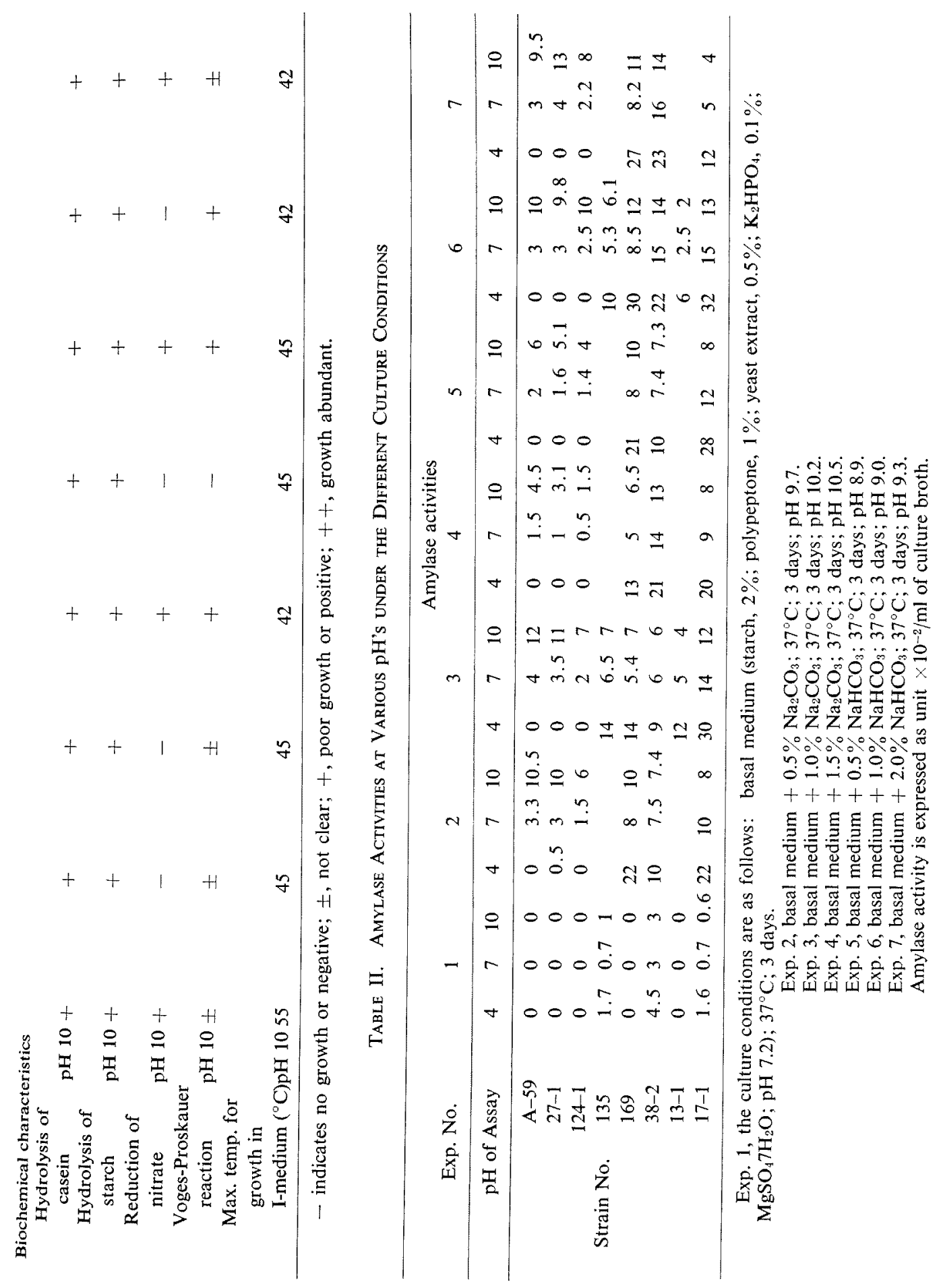


Table III. Thermal Stabilities of Amylases

Enzymes were dissolved in $\mathrm{pH} 10$ Borax buffer and incubated for $15 \mathrm{~min}$ at indicated temperatures. Residual activity was measured at $\mathrm{pH} 10$.

\begin{tabular}{|c|c|c|c|c|c|}
\hline \multirow{3}{*}{ Strain No. } & \multirow{3}{*}{ Type } & \multicolumn{4}{|c|}{ Residual activity ( $\%$ ) } \\
\hline & & \multicolumn{2}{|c|}{$\begin{array}{c}55^{\circ} \mathrm{C} \\
\mathrm{CaCl}_{2} 10 \mathrm{~mm}\end{array}$} & \multicolumn{2}{|c|}{$\begin{array}{c}60^{\circ} \mathrm{C} \\
\mathrm{CaCl}_{2} 10 \mathrm{~mm}\end{array}$} \\
\hline & & - & + & - & + \\
\hline$A-40-2^{\dagger}$ & 1 & 4.6 & 55 & 0 & 5 \\
\hline$A-59$ & 1 & 7 & 67 & 0 & 5 \\
\hline $27-1$ & 1 & 8 & 42 & 0 & 0 \\
\hline $124-1$ & 1 & 6 & 22 & 0 & 0 \\
\hline 135 & 2 & 66 & 95 & 4 & 20 \\
\hline 169 & 2 & 57 & 95 & 7 & 25 \\
\hline $38-2$ & 3 & 94 & 100 & 35 & 85 \\
\hline $17-1$ & 4 & 87 & 97 & 5 & 35 \\
\hline 13 & 4 & 48 & 73 & 0 & 0 \\
\hline
\end{tabular}

+ See ref. 1.

Table IV. Propertifs of Amylases of Alkalophulic Bacteria

\begin{tabular}{|c|c|c|c|c|c|c|}
\hline \multirow{2}{*}{ Type } & \multirow{2}{*}{$\begin{array}{l}\text { Strain } \\
\text { No. }\end{array}$} & \multirow{2}{*}{ Opt. $\mathrm{pH}^{a 1}$} & act. $10^{b)}$ & \multirow{2}{*}{$\mathrm{pH}$ stability ${ }^{c}$} & \multirow{2}{*}{$\begin{array}{l}\text { Protection } \\
\text { by } \mathrm{Ca}^{2+}\end{array}$} & \multirow{2}{*}{$\mathrm{DEAE}^{d 1}$} \\
\hline & & & Max. act & & & \\
\hline \multirow[t]{4}{*}{1} & A- $40-2$ & 10.5 & 1.0 & $7 \sim 9.5$ & + & + \\
\hline & A-59 & 10.5 & 1.0 & $7 \sim 9.5$ & + & + \\
\hline & $27-1$ & 10.5 & 1.0 & $7 \sim 9$ & + & + \\
\hline & $124-1$ & 10.5 & 1.0 & $7 \sim 9$ & + & + \\
\hline \multirow[t]{2}{*}{2} & 135 & $4 \sim 4.5,10$ & 0.8 & $7 \sim 9$ & + & + \\
\hline & 169 & $4 \sim 4.5,10$ & 0.7 & $7 \sim 9$ & + & - \\
\hline 3 & $38-2$ & $4.5,9.0$ & 0.6 & $5.0 \sim 10.5$ & + & - \\
\hline \multirow[t]{2}{*}{4} & 13 & 4.5 & 0.3 & $6.5 \sim 10$ & + & - \\
\hline & $17-1$ & 4.5 & 0.35 & $6.5 \sim 10$ & + & - \\
\hline
\end{tabular}

Commercial B. subtilis ${ }^{e}$ amylase 6 0.05

a) optimum $\mathrm{pH},{ }^{b}$ ) maximum activity/activity at $\left.\mathrm{pH} 10.0,0\right) 50 \%$ of the activity was remained, d) adsorption by DEAE-cellulose equilibrated with $0.1 \mathrm{M} \mathrm{Na} \mathrm{CO}_{3}$ (pH 9.0); +, adsorped; -, not adsorped, ${ }^{e)}$ obtained from Nagase Sangyo Co. 


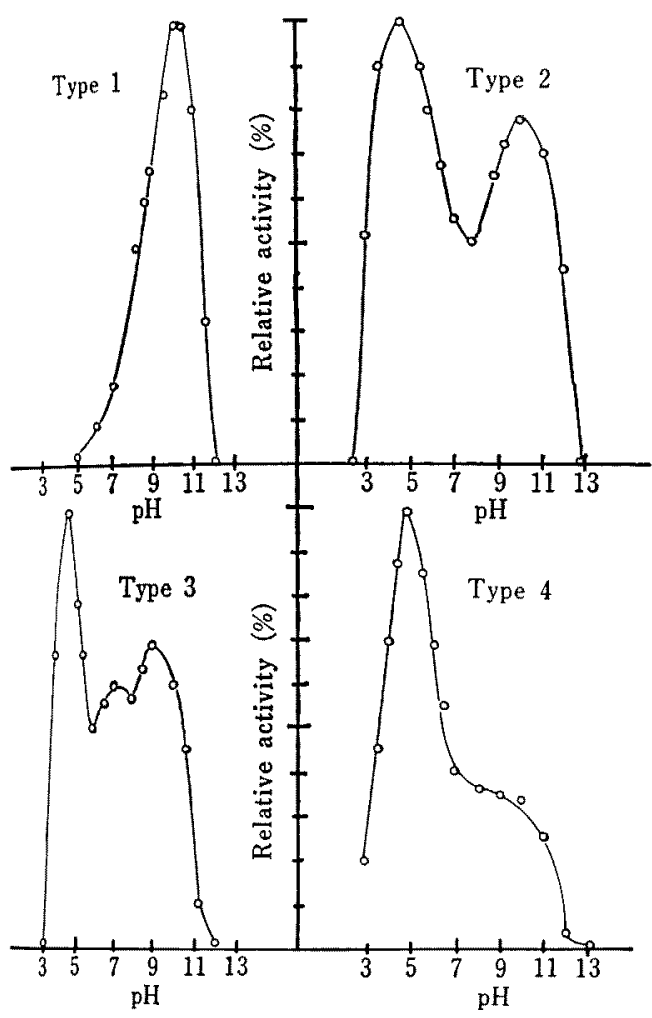

Fig. 1. Effect of pH on Enzyme Activity. See the text for the experimental details. has type $3 \mathrm{pH}$-activity curve was heat stable and about $50 \%$ of activities which measured at $\mathrm{pH} 4.5$ and 10 were remained after the incubation at $65^{\circ} \mathrm{C}$ for $40 \mathrm{~min}$. Effects of $\mathrm{pH}$ on stability of the enzymes were investigated in the buffers desribed above containing $10 \mathrm{~mm}$ $\mathrm{CaCl}_{2}$. The mixture was incubated at $50^{\circ} \mathrm{C}$ for $15 \mathrm{~min}$ and the residual activity was assayed at $\mathrm{pH}$ 10.0. Table IV shows $\mathrm{pH}$ range, under which more than $70 \%$ of the activity was remained. When the culture filtrate was loaded on a column of DEAE-cellulose equilibrated with $0.1 \mathrm{M} \mathrm{Na}_{2} \mathrm{CO}_{3}$ (pH was adjusted to 9.5 with $\mathrm{HCl}$ ), type 1 was completely adsorped by DEAE-cellulose. These results are summarizes in Table IV.

The authors thank Dr. Y. Ikeda for his suggestion and critical reading of the manuscript.

\section{REFERENCES}

1) K. Horikoshi, Agr. Biol. Chem., 35, 1783 (1971). 